\title{
Growth and grazing response of a ciliate feeding on the red tide dinoflagellate Gyrodinium aureolum in monoculture and in mixture with a non-toxic alga
}

\author{
Per Juel Hansen* \\ National Environmental Research Institute, Department of Marine Ecology and Microbiology, Frederiksborgvej 399 , \\ DK-4000 Roskilde, Denmark
}

\begin{abstract}
The effect of the red tide dinoflagellate Gyrodinium aureolum on the growth of the tintinnid ciliate Favella ehrenbergii was studied. The ciliate is unable to sustain growth with this alga as the only food source, irrespective of concentration. Ciliate survival decreases at very high concentrations of $G$. aureolum probably due to toxic substances exuded from $G$. aureolum to the medium. This assumption is supported by the fact that growth of the ciliate is not affected by even very high concentrations of a non-toxic dinoflagellate, Heterocapsa triquetra. However, direct attempts to demonstrate toxic effects of exudates, using filtrates of dense cultures of $G$. aureolum, failed. Growth and grazing experiments were also carried out in which the ciliate was fed mixtures of $G$. aureolum and $H$. triquetra at relatively low algal concentrations. The growth of the ciliate was unaffected until $G$. aureolum accounted for about $70 \%$ of the total biomass. In cases where $G$. aureolum accounted for about $90 \%$ of the algal biomass, the growth rate of the ciliate was reduced by less than $25 \%$. Grazing experiments demonstrated that $F$. ehrenbergii cannot selectively avoid ingestion of $G$. aureolum
\end{abstract}

KEY WORDS: Red-tide dinoflagellate Ciliate Growth Grazing Toxic algae Gyrodinium aureolum

\section{INTRODUCTION}

Gyrodinium aureolum was first described from the northeast coast of the USA (Hulburt 1957), but the first bloom of $G$. aureolum was reported from European waters along the coasts of Norway (Braarud \& Heimdal 1970 ). Since then, the species has regularly formed blooms along the west coasts of Europe and the northeast coast of the USA (e.g. Partensky \& Sournia 1986, Mahoney et al. 1990).

The connection between blooms of Gyrodinium aureolum and harmful effects on fish and bottom invertebrates is well documented (Braarud \& Heimdal 1970. Helm et al. 1974, Tangen 1977, Southgate et al. 1984, Potts \& Edwards 1987, Mahoney et al. 1990)

\footnotetext{
- Present address: Marine Biological Laboratory (University of Copenhagen), DK-3000 Helsingør, Denmark
}

Both oxygen depletion and the production of toxins have been suggested as the cause of these effects. Experiments in which fish or mussels were exposed either to natural blooms or to laboratory cultures of $G$. aureolum suggest that the harmful effect is due to the production of toxins rather than to oxygen depletion (Widdows et al. 1979, Jones et al. 1982, Roberts et al. 1983, Turner et al. 1984, Nielsen \& Strømgren 1991). Recently, 2 toxins, a glucolipid (1-acyl-3-digalactosylglycerol) and a fatty acid (octadecapentaenoic acid) have been isolated from G. aureolum (Yasumoto et al. 1990). These toxins damage membranes of blood cells causing cell lysis, and they are often referred to as hemolysins or ichthyotoxins due to their effect on blood cells and fish (Yasumoto et al. 1987). At present a chemical method for the quantification of these toxins does not exist, and our knowledge regarding the variability of toxin production is restricted. 
Blooms of Gyrodinium aureolum often last for a considerable period of time (several weeks), suggesting a mechanism which inhibits grazing. The literature does not provide much information on this subject, but recent laboratory experiments have demonstrated significantly reduced grazing activity and egg production rates of copepods when fed $G$. aureolum in monoculture (Gill \& Harris 1987). Bjørnsen \& Nielsen (1991) also found a drastic reduction in microzooplankton concentration at a depth coinciding with a subsurface layer of $G$. aureolum in the Kattegat.

The aim of the present work was to study the ability of a ciliate to feed and grow when fed a monoculture of Gyrodinium aureolum. In addition, the effect of the presence of an alternative prey on the feeding and growth rates of the ciliate was studied.

\section{MATERIALS AND METHODS}

The algae. The potentially toxic dinoflagellate Gyrodinium aureolum Hulburt was isolated from Norwegian waters by Karl Tangen in 1977, whereas the nontoxic dinoflagellate Heterocapsa triquetra (Ehrenb.) Stein was isolated by Gert Hansen from the Oresund, Denmark, in 1986. Both species were provided by the Scandinavian Culture Collection, Botanical Institute, Department of Fungi and Algae, Copenhagen University. The algae were grown in $\mathrm{B}$ medium (Hansen 1989 ) based on $30 \%$ seawater and with the omission of silicate as non-axenic batch cultures under constant illumination $\left(60 \mu \mathrm{mol}\right.$ photons $\left.\mathrm{m}^{-2} \mathrm{~s}^{-1}\right)$ at $15 \pm 1^{\circ} \mathrm{C}$. Cells were counted using a $1 \mathrm{ml}$ Sedgewick-Rafter chamber, and each count was based on at least 400 cells. The dimensions of the algae were determined by measurements of Lugol fixed cells $(n=40)$ under the microscope, and volume was estimated assuming the shape of a double cone for $H$. triquetra and of an ellipsoid for $G$. aureolum. The carbon content of the algae was measured by filtering dense algal suspensions ( 4 to $20 \mathrm{ml}$ ) onto $6 \mathrm{~mm}$ precombusted $\left(500^{\circ} \mathrm{C}\right)$ $\mathrm{GF} / \mathrm{F}$ filters. Filters were dried at $40^{\circ} \mathrm{C}$ and stored for $24 \mathrm{~h}$ prior to infrared gas analysis. Each disc was combusted at $960^{\circ} \mathrm{C}$ in a flow of oxygen that carried the produced $\mathrm{CO}_{2}$ to a Hartman-Braun carbon analyzer,

Table 1. Gyrodinium aureolum and Heterocapsa triquetra. Cell dimensions, volumes and carbon content of the studied dinoflagellates

\begin{tabular}{|c|c|c|c|}
\hline Dinoflagellates & $\begin{array}{l}\text { Cell dimensions } \\
I \times b \times d(\mu \mathrm{m})\end{array}$ & $\begin{array}{l}\text { Volume } \\
\left(\mu \mathrm{m}^{3}\right)\end{array}$ & $\begin{array}{l}\text { Carbon content } \\
\left(\mathrm{pg} C \mathrm{cell}^{-1}\right)(\mathrm{SE})\end{array}$ \\
\hline Heterocapsa triquetra & $25 \times 17 \times 17$ & 1890 & $507(50)$ \\
\hline Gyrodinium aureolum & $26 \times 22.5 \times 16$ & 5200 & $651(68.5)$ \\
\hline
\end{tabular}

equipped with a Hewlett Packard integrator. Each measurement was based on between 3 and 6 replicates and 3 reference spots without sample. Weighted crystals of oxalic acid were used as standards. The dimensions as well as carbon content are given in Table 1.

The ciliate. This work was based on several clones of the tintinnid ciliate Favella ehrenbergii (Clap. et Lach.) Jörg., isolated from surface water samples from the Limfjord, Denmark, in 1992, 1993 and 1994. The ciliates were initially grown in a Nunclon multidish with $2 \mathrm{ml}$ of Heterocapsa triquetra suspension at a concentration of $10^{3}$ to $10^{4}$ cells $\mathrm{ml}^{-1}$. Subsequently they were transferred to petri dishes or tissue culture flasks containing 40 to $60 \mathrm{ml} \mathrm{B}$ medium, to which $H$. triquetra was regularly added (at concentrations of $10^{3}$ to $10^{4}$ cells $\mathrm{ml}^{-1}$ ). The cultures were transferred weekly.

Experimental procedures. All experiments were carried out at $15 \pm 1^{\circ} \mathrm{C}$ and at a salinity of $30 \%$ using the $\mathrm{B}$ growth medium (Hansen 1989). Experiments were carried out at continuous low-intensity light (between 5 and $15 \mu \mathrm{mol} \mathrm{m} \mathrm{m}^{-2} \mathrm{~s}^{-1}$ ) to ensure no or very low growth of the prey during the experiments. In the growth/survival experiments the changes in algal density during incubation never exceeded 15\%. In order to eliminate excessive changes especially at low prey concentrations, only a part of the ciliate population was transferred; the rest was fixed and counted.

Monoculture experiments. Experiments were conducted to study the growth response of Favella ehrenbergii fed either Gyrodinium aureolum or Heterocapsa triquetra in monoculture. Growth experiments in which $F$. ehrenbergii was fed $H$. triquetra were conducted at prey concentrations ranging from 35 to $5000 \mathrm{cells} \mathrm{ml}^{-1}$ The ciliates were adapted to the experimental suspension for 1 or $2 \mathrm{~d}$ prior to the experiments. The experiments were carried out in $61.5 \mathrm{ml}$ tissue culture flasks. Using a micropipette, 25 to 200 ciliates were added to each flask which was mounted on a plankton wheel (2 rpm) The duration of the experiment was ca $24 \mathrm{~h}$, at which time the experiment was terminated with Lugol's iodine with acetic acid. Three replicates were set up for each food concentration. The prey concentration was measured at the beginning as well as at the end of each experiment and the average prey concentration determined: $C=\left(C_{0}-C_{1}\right)\left(\ln C_{0}-\ln C_{t}\right)^{-1}$, where $C_{0}=$ the concentration of algae at the beginning of the experiment and $C_{t}=$ concentration of cells at the end; $t=$ incubation time (h). The instantaneous growth rates of the ciliates were determined as: $\mu=$ $\left(\ln N_{t}-\ln N_{0}\right) t^{-1}$, where $N_{0}=$ the number of cells at the beginning of the experiment and $N_{t}=$ the number of cells at the end $t=$ incubation time. The growth rate $(\mu)$ as a function of food 
concentration was fitted to Michaelis-Menten kinetics: $\mu=\mu_{\mathrm{m}} C\left(K_{\mathrm{m}}+C\right)^{-1}$, where $\mu=$ growth rate $\left(\mathrm{h}^{-1}\right), \mu_{\mathrm{m}}=$ maximal growth rate, $C$ = average prey concentration, and $K_{\mathrm{m}}=$ half-saturation constant

Growth/survival experiments in which Favella ehrenbergii was fed Gyrodinium aureolum were carried out at prey concentrations ranging from 200 to 2500 cells $\mathrm{ml}$ !. Algal cultures were inoculated and allowed to grow into late exponential growth phase (cell concentration between 30000 and 40000 cells $\mathrm{ml}^{-1}$ ) and maintained at this level by daily dilution. To attain experimental concentrations of between 200 and 2500 cells $\mathrm{ml}^{-1}$, the culture was diluted with fresh B medium. The experiments were carried out in $61.5 \mathrm{ml}$ tissue culture flasks. Using a micropipette, 24 ciliates were added to each flask which was mounted on a plankton wheel (2 rpm). The ciliates were transferred daily to a fresh algal suspension and counted. The duration of the experiments was $8 \mathrm{~d}$.

Additional experiments were carried out in which Favella ehrenbergii was fed Gyrodinium aureolum at high concentrations (range 2500 to 30000 cells $\mathrm{ml}^{-1}$ ). These experiments were carried out in multidishes ( $2 \mathrm{ml}$ algal suspension). Each experiment was initiated with $1 F$, ehrenbergii cell per chamber, and 24 replicates were made for each algal concentration. The ciliates were transferred daily to a fresh algal suspension and counted. Growth experiments were conducted with Heterocapsa triquetra (concentration range: 5000 to 60000 cells $\mathrm{ml}^{-1}$ ) for comparison with a non-toxic form.

Exudate experiments. In order to study toxic effects on the growth of Favella ehrenbergii due to toxic substances exuded by Gyrodinium aureolum into the medium, 2 kinds of experiments were carried out. In the first kind of experiments, cylindrical chambers (dimensions: $20 \times 30 \mathrm{~mm}$ ) were made, in which 2 equally large parts were separated from the each other by plankton gauze (mesh size $5 \mu \mathrm{m}$ ). In this way, cells of $G$. aureolum were separated from cells of Heterocapsa triquetra, allowing an exchange of dissolved substances. Experiments were carried out by applying a dense suspension of G. aureolum 440000 or 80000 cells $\mathrm{ml}^{-1}$ ) on 1 side of the gauze and a suspension of $H$. triquetra $\left(10000\right.$ cells $\left.\mathrm{ml}^{-1}\right)$ on the other. The growth/survival response of $F$. ehrenbergii was studied by inoculating 15 ciliates on both sides of the plankton gaze. The ciliates were transferred daily to fresh suspensions and counted. The duration of the experiment was $5 \mathrm{~d}$. Between 3 and 4 replicates were made. In another experiment, a dense suspension of $G$. aureolum (about 60000 cells $\mathrm{ml}^{-1}$ ) was centrifuged $(100 \times \mathrm{g})$ and the supernatant $(2 \mathrm{ml})$ added to multidishes prior to the inoculation of ciliates. Filtered $B$ medium served as a blank
Mixture experiments. Experiments were conducted to study the growth and grazing of Favella ehrenbergii exposed to mixtures of Gyrodinium aureolum and Heterocapsa triquetra. In the first set of experiments the ratio between the 2 algae was kept constant. The following mixtures were used: 200/200, 500/500, 1000/ $1000,2000 / 2000,4000 / 4000$ cells $\mathrm{ml}^{-1}$ In another experiment, the concentration of $G$. aureolum was kept constant ( 2000 cells $\mathrm{ml}^{-1}$ ), while different concentrations of $H$. triquetra were used $(200,600,2000,6000$ and 20000 cells $\mathrm{ml}^{-1}$ ). All experiments were carried out in tissue culture flasks (61.5 ml) and mounted on a plankton wheel. The ciliates were transferred daily to fresh suspensions and counted. The duration of the experiments was between 6 and $8 \mathrm{~d}$.

Grazing experiments were also carried out in which ciliates were fed mixtures of Gyrodinium aureolum and Heterocapsa triquetra. The concentration of cells was kept constant, while the ratio between the 2 algae was changed. The following mixtures of $\mathrm{H}$. trique$\mathrm{tra} / \mathrm{G}$. aureolum were used: $250 / 2250,750 / 1750,1250 /$ $1250,1750 / 750,2250 / 250$. Feeding rates were measured by adding between 100 ciliates to $61.5 \mathrm{ml}$ algal suspension, using Nunclon flasks. The ciliates were allowed to graze for ca $40 \mathrm{~h}$, whereafter they were fixed with Lugol (final concentration $1 \%$ ). The grazing rates were determined as the reduction in particle concentration according to Frost (1972).

\section{RESULTS}

The growth rate of Favella ehrenbergii was satiated at a prey concentration of ca 1000 Heterocapsa triquetra cells $\mathrm{ml}^{-1}$ reaching a maximum of $0.034 \mathrm{~h}^{-1}$, which corresponds to a doubling time of $20 \mathrm{~h}$ (Fig. 1, Table 2). The growth remained positive down to a prey concentration of 35 cells $\mathrm{ml}^{-1}\left(=20 \mu \mathrm{g} \mathrm{C} \mathrm{l}^{-1}\right)$. Accepting a threshold prey concentration of 10 cells $\mathrm{ml}^{-1}$, these data fit Michaelis-Menten kinetics closely $\left(R^{2}=0.91\right.$, Statgraphics $^{2}$ 2.0).

Favella ehrenbergii was unable to sustain growth when Gyrodinium aureolum was offered as the only food source, irrespective of the algal concentration (Figs. $2 \& 3$, Table 3). The growth/survival response was similar within algal concentrations of 500 to 10000 cells $\mathrm{ml}^{-1}$ : the ciliates divided up to 3 times within the first $3 \mathrm{~d}$, whereafter they gradually died. After $8 \mathrm{~d}$ the number of ciliates was heavily reduced. At lower concentrations ( 200 cell $\mathrm{ml}^{-1}$ ) no initial increase in ciliate numbers was found, and the cell number declined slowly throughout the experiment. At higher concentrations of $G$. aureolum (20000 to 30000 cells $\mathrm{ml}^{-1}$ ), a quicker response was observed, and no ciliates were left after $6 \mathrm{~d}$ of exposure. At the highest concentration 


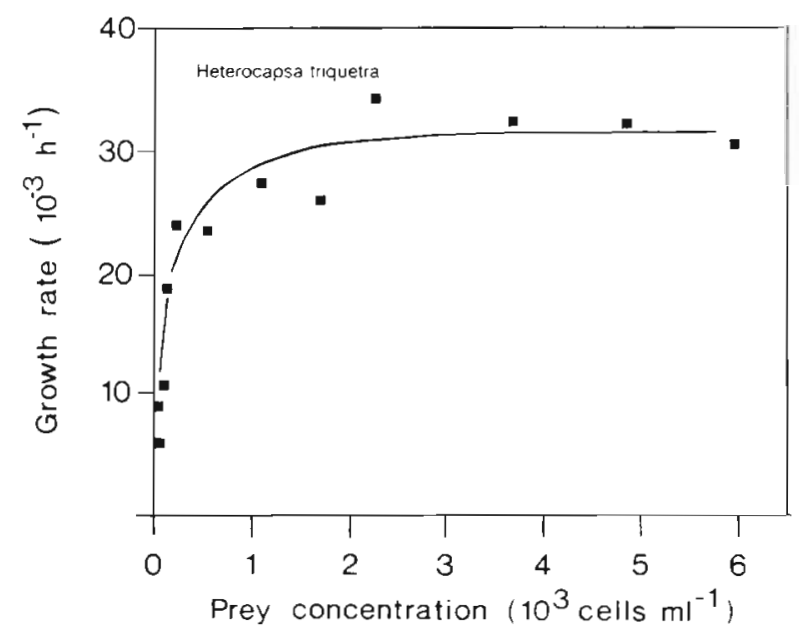

Fig. 1. Favella ehrenbergii. Growth rate as a function of cell concentration of the non-toxic dinoflagellate Heterocapsa triquetra. Data points represents treatment means $(n=4)$. Curve is numerically fitted to Michaelis-Menten kinetics: $\mu=0.032$ $\left(C_{p}-10\right)\left[\left(118+\left(C_{p}-10\right)\right]^{-1}\right.$. For mean values $\pm 1 \mathrm{SE}$, see Table 2

the ciliates died within $2 \mathrm{~d}$, which was as quickly as if they had not been fed at all. In contrast to this, $F$ ehrenbergii grew well even at extremely high concentrations of Heterocapsa triquetra (Fig. 4). Experiments in which a dense suspension of $G$. aureolum was separated from a suspension of $H$. triquetra using plankton gauze failed to prove any toxic effects. Likewise, filtrates from dense cultures of $G$. aureolum failed to have any negative effect on the growth or survival response of the ciliate (Fig. 5).

Experiments in which Favella ehrenbergii was exposed to mixtures Gyrodinium aureolum and Heterocapsa triquetra at a fixed cell concentration ratio

Table 2. Favella ehrenbergi. Growth rate as a function of cell concentration of the non-toxic dinoflagellate Heterocapsa triquetra. Growth rate values given as mean values $\pm 1 \mathrm{SE}$, $\mathrm{n}$ : number of replicates

\begin{tabular}{|ccc|}
\hline $\begin{array}{c}\text { Mean prey } \\
\text { concentration } \\
\left.\text { (cells } \mathrm{ml}^{-1}\right)\end{array}$ & $\begin{array}{c}\text { Mean growth rate } \\
\pm 1 \mathrm{SE}\left(\mathrm{h}^{-1}\right)\end{array}$ & $\mathrm{n}$ \\
\hline 37.6 & $0.0090 \pm 0.0031$ & 4 \\
59 & $0.0060 \pm 0.0021$ & 4 \\
99 & $0.0108 \pm 0.0046$ & 4 \\
131 & $0.0187 \pm 0.0055$ & 4 \\
210 & $0.0239 \pm 0.0020$ & 4 \\
539 & $0.0235 \pm 0.0015$ & 4 \\
1088 & $0.0274 \pm 0.0012$ & 4 \\
1679 & $0.0261 \pm 0.0034$ & 3 \\
2251 & $0.0343 \pm 0.0006$ & 4 \\
3660 & $0.0324 \pm 0.0008$ & 4 \\
4834 & $0.0323 \pm 0.0011$ & 4 \\
5941 & $0.0305 \pm 0.0004$ & 4 \\
\hline
\end{tabular}

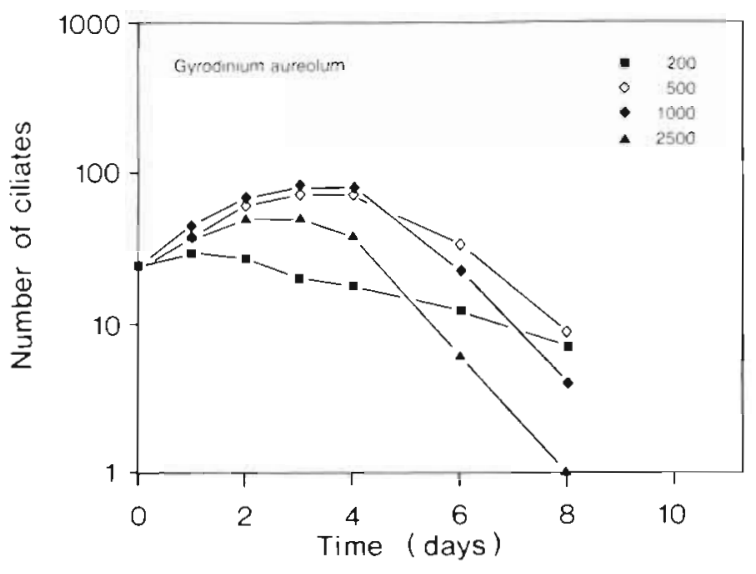

Fig. 2. Favella ehrenbergii. Growth/survival response to low concentrations of Gyrodinium aureolum. Numbers refer to cells $\mathrm{ml}^{-1}$ Late exponential cultures were used. Ciliates were transferred daily to a fresh suspension of dinoflagellates

(50\% of each) showed that the growth rate of $F$. ehrenbergii was unaffected within the concentration range of 1000 to 8000 cells $\mathrm{ml}^{-1}$. At 400 cells $\mathrm{ml}^{-1}$ the growth rate of the ciliate was reduced due to food limitation (see Fig. 1). Experiments in which F. ehrenbergii was exposed to a fixed cell concentration of $G$. aureolum (2000 cells $\mathrm{ml}^{-1}$ ) and different concentrations of $H$. triquetra showed that the growth rate of $F$. ehrenbergii was unaffected until $G$. aureolum accounted for about $70 \%$ of the total biomass (Figs. $6 \& 7$ ). Even in cases where $G$. aureolum accounted for about $90 \%$ of the algal biomass, the growth rate of the ciliate was only slightly reduced (reduction less than $25 \%$, Fig. 7).

Grazing experiments, in which Favella ehrenbergii was fed mixtures of Gyrodinium aureolum and Hetero-

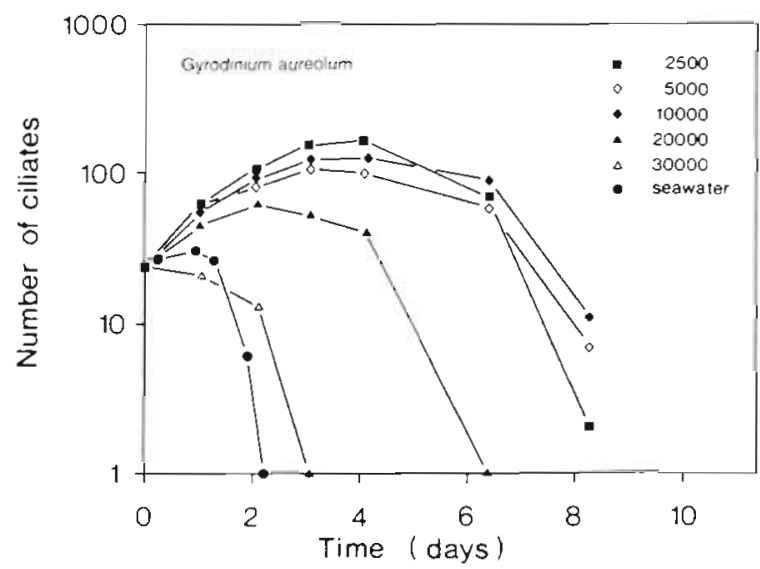

Fig. 3. Favella ehrenbergii. Growth/survival response to high concentrations of Gyrodinium aureolum. Seawater refers to starving ciliates; otherwise as stated in Fig. 2. For mean values $\pm 1 \mathrm{SE}_{\text {, }}$ see Table 3 
Table 3. Favella ehrenbergii. Growth/survival response to different concentrations of Gyrodinium aureolum. Values refer to average number of ciliates in each well \pm 1 SE $(n=24)$

\begin{tabular}{|c|c|c|c|c|c|c|}
\hline \multirow[t]{2}{*}{ Time (h) } & \multicolumn{5}{|c|}{ Algal concentration (cells $\mathrm{ml}^{-1}$ ) } & \multirow[t]{2}{*}{ Seawater } \\
\hline & 2500 & 5000 & 10000 & 20000 & 30000 & \\
\hline 5.5 & & & & & & $1.13 \pm 0.09$ \\
\hline 23 & $2.25 \pm 0.19$ & $2.63 \pm 0.18$ & $2.38 \pm 0.15$ & $1.92 \pm 0.13$ & $0.88 \pm 0.12$ & $1.29 \pm 0.11$ \\
\hline 29.5 & & & & & & $1.13 \pm 0.11$ \\
\hline 46 & & & & & & 0.25 \\
\hline 49 & $4.50 \pm 0.36$ & $3.54 \pm 0.26$ & $3.83 \pm 0.29$ & $2.58 \pm 0.20$ & $0.14 \pm 0.14$ & 0.00 \\
\hline 71 & $6.42 \pm 0.62$ & $4.42 \pm 0.50$ & $5.17 \pm 0.41$ & $2.25 \pm 0.24$ & & \\
\hline 105 & $7.08 \pm 0.87$ & $4.33 \pm 0.60$ & $5.25 \pm 0.52$ & $1.67 \pm 0.28$ & & \\
\hline 153 & $2.88 \pm 0.73$ & $2.50 \pm 0.59$ & $3.71 \pm 0.45$ & $0.04 \pm 0.04$ & & \\
\hline 198 & $0.08 \pm 0.06$ & $0.29 \pm 0.12$ & $0.46 \pm 0.18$ & 0.00 & & \\
\hline
\end{tabular}

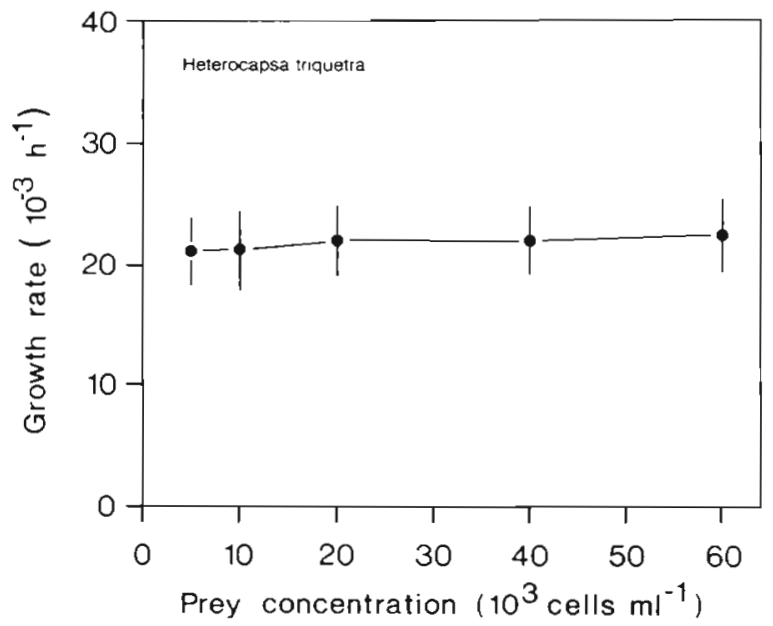

Fig. 4. Favella ehrenbergu. Growth rate as a function of cell concentration of the non-toxic dinoflagellate Heterocapsa triquetra at high cell concentrations. Data points represent treatment means $\pm 1 \mathrm{SE}(\mathrm{n}=6)$, otherwise as stated in Fig. 2 capsa triquetra at different ratios, keeping the total prey concentration constant, demonstrated that the ciliate ingests $G$. aureolum with a slightly lower efficiency (Fig. 8).

\section{DISCUSSION}

Gyrodinium aureolum has been reported to have a maximum growth rate of between 0.012 and $0.015 \mathrm{~h}^{-1}$ at $20^{\circ} \mathrm{C}$ (Paasche et al. 1984, Garcia \& Purdie 1992). The obtained maximum growth rate of the ciliate Favella ehrenbergii was $0.034 \mathrm{~h}^{-1}$, thus exceeding that of $G$. aureolum by a factor of 2 . In combination with the fact that $F$. ehrenbergii is capable of growth at low prey concentrations, this suggests that the ciliate potentially may be an important grazer of $G$. aureolum in nature. However, the present study suggests that $F$. ehrenbergii cannot sustain growth when feeding on $G$. aureolum as the only food source, irrespective of the prey concentration (Figs. 2 \& 3). If a population of $F$. ehrenbergii is subjected to starvation, a few individu-
Fig. 5. Favella ehrenbergii. Growth/survival response to exudates from Gyrodinium aureolum. Data points refer to treatment means of between 3 and 4 replicates. (A, B) Growth experiments in which 2 chambers have been separated by plankton gaze (mesh size $5 \mu \mathrm{m}$ ), allowing passage of dissolved substances, but not of algae. (A) In one chamber, Heterocapsa triquetra were added at a concentration of 10000 cells $\mathrm{ml}^{-1}(\bullet)$, while a suspension of $40000 \mathrm{G}$. aureolum $\mathrm{ml}^{-1}$ was added to the other chamber (O). (B) Same as in (A), but a higher concentration of Gyrodinium aureolum was added to the second chamber $\left(80000\right.$ cells $\left.\mathrm{ml}^{-1}\right)$. (C) Survival response to filtrate from a dense $\left(60000\right.$ cells $\left.\mathrm{ml}^{-1}\right)$ culture of $G$. aureolum $(\diamond)$ and to filtered B medium $(\bullet)$
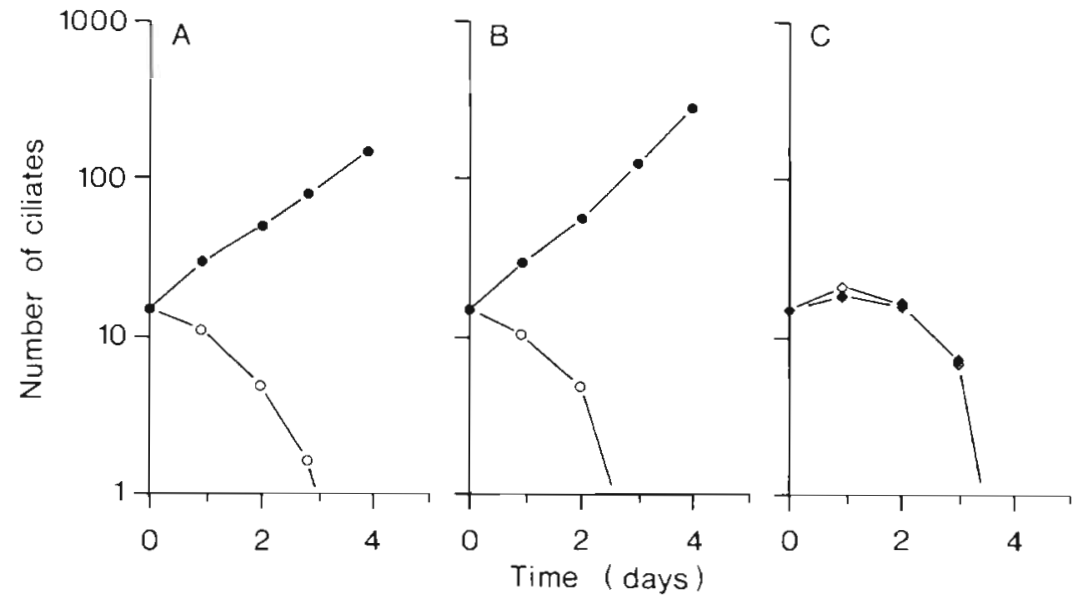


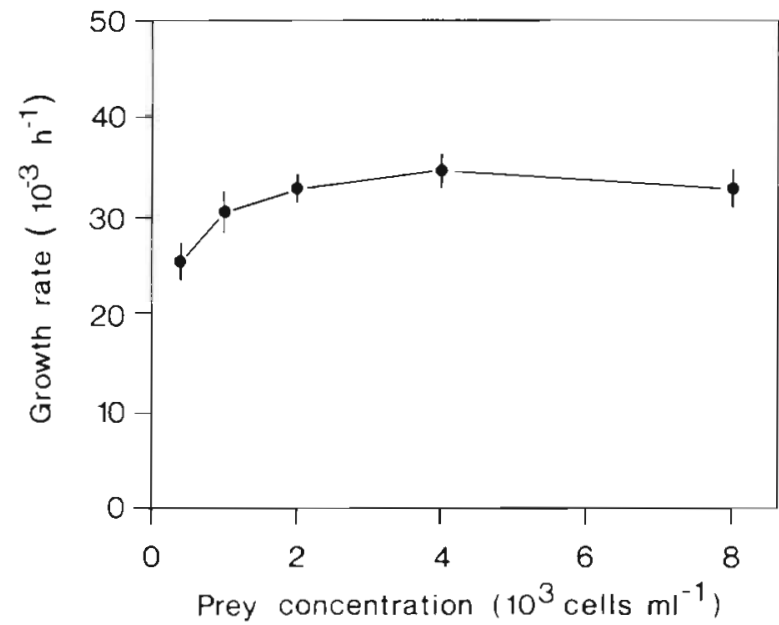

Fig. 6. Favella ehrenbergii. Growth rate as a function of total cell concentration of Gyrodinium aureolum and Heterocapsa triquetra at a fixed relative proportion (50\% in numbers).

Data points refer to treatments means $\pm 1 \mathrm{SE}$

als will divide once, before they eventually die within $3 \mathrm{~d}$. Initial ingestion of $G$. aureolum is indicated by the fact that $F$. ehrenbergii divides up to 3 times during the first 2 to $3 d_{1}$, when fed this alga at concentrations of 500 to 10000 cells $\mathrm{ml}^{-1}$ (Figs. 2 \& 3). It has previously been shown that $G$. aureolum is a poor food source for copepods. Copepods fed monocultures of $G$. aureolum at low concentrations have virtually no egg production and suffer mortality rates comparable to those obtained in filtered seawater (Gill \& Harris 1987). Reduced filtration rates have also been demonstrated in rotifers and copepods fed monocultures of the

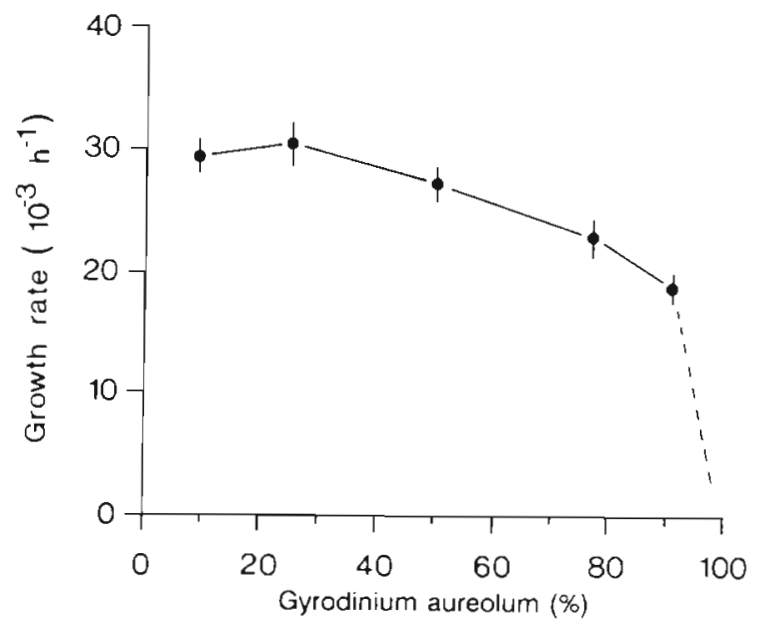

Fig. 7. Favella ehrenbergii. Growth rate as a function of the fraction of the total cell cencentration made up by Gyrodinium aureolum. Concentration of $G$. aureolum was kept constant (2000 cells m. $\left.\mathrm{I}^{-1}\right)$, while the concentrations of Heterocapsa triquetra were increased (200 to 6000 cells ml-1). Data points refer to treatments means $\pm 1 \mathrm{SE}$

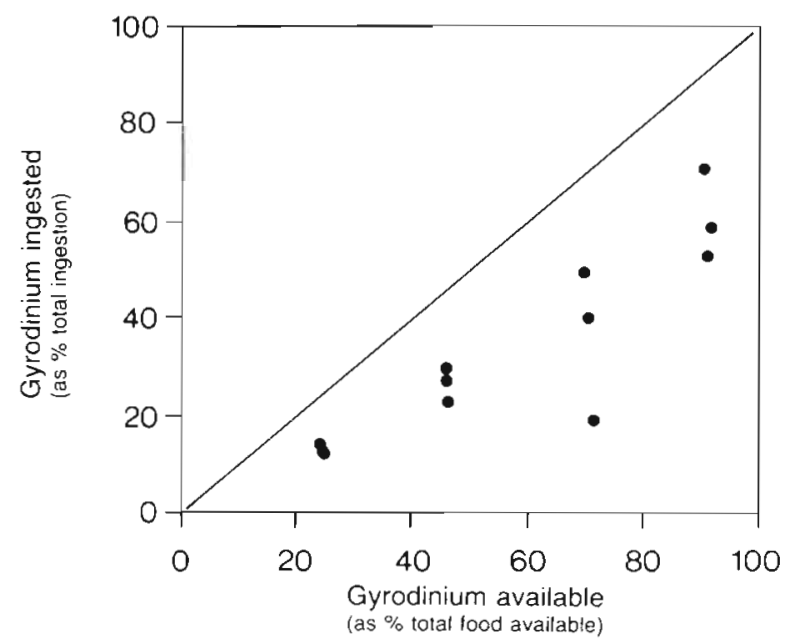

Fig. 8. Favella ehrenbergii. Particle uptake at a fixed total concentration ( 2500 cells $\mathrm{ml}^{-1}$ ) of a mixture of Heterocapsa triquetra and Gyrodinium aureolum expressed as \% uptake of G. aureolum as a function of \% G. aureolum present in the algal suspension. Data points refer to individual values

closely related Gymnodinium mikimotoi Mikye and Kominani (= G. nagasakiense; Abé \& Hirayama 1979 , Uye \& Takamatsu 1990).

In the present study, the negative effect of Gyrodinium aureolum on the growth and survival of $\mathrm{Fa}$ vella ehrenbergii at algal concentrations less than 10000 cells $\mathrm{ml}^{-1}$ is without doubt caused by ingestion of the alga. This is clearly demonstrated in the mixture experiments, in which $F$. ehrenbergii was exposed to increasing concentrations of $G$. aureolum and Heterocapsa triquetra at a fixed cell concentration ratio (compare Figs. 2, $3 \& 6$ ). If dissolved substances were toxic at low concentrations, the growth rate of $F$. ehrenbergii would decrease with increasing concentrations of $G$. aureolum. In fact, the ciliate grows at a rate which is similar to that obtained on a pure diet of $H$. triquetra (compare Figs. 1 \& 6).

Substances excreted into the medium by Gyrodinium aureolum have previously been reported to suppress the growth of other algae (e.g. diatoms; Gentien \& Arzul 1990, Arzul et al. 1993) and it has also been suggested that these substances were responsible for fish kills (Jones et al, 1982). In the latter case, the toxic substances appear to affect the gills of the fish, causing necrosis of the gill filaments (Jones et al. 1982, Turner et al. 1984). The negative effect on the growth rate of Favella ehrenbergii increased at high concentrations of $G$. aureolum (above 10000 cells $\mathrm{ml}^{-1}$ ) indicating toxic effects of exudates. That this is not an unspecific response due to leakages of substances in general is supported by the fact that $F$. ehrenbergii grows well even at extremely high concentrations of Heterocapsa triquetra (Fig. 4). However, 
experiments with filtrates from dense cultures of $G$ aureolum failed to produce any toxic effect on $F$. ehrenbergii (Fig. 5). The lack of toxic effects of filtrate originating from dense $G$. aureolum cultures in the present study may be due to a rapid turnover of the toxin(s). In a previous paper, it was demonstrated that the toxic effects of filtrates from another red tide dinoflagellate, Alexandrium tamarense (Lebour) Balech, disappeared within hours (Hansen 1989).

Thus, laboratory studies conducted so far suggest that both proto- and metazooplankton are unable to sustain growth when fed Gyrodinium aureolum in monoculture. This may be due either to the lack of substances which are essential for the growth of zooplankton or to the production of toxic substances by the alga. The fact that neither proto-nor metazooplankton which are exposed to low concentrations of $G$. aureolum suffer from acute death suggests that toxins are not involved. However, it is worthwhile to note that the dinoflagellate Alexandrium tamarense, which produces neurotoxins, does not elicite acute death in copepods which have been exposed. In the case of Favella ehrenbergii, the present study suggests that toxic substances exuded by the alga into the medium may partly be responsible for the observed mortality at extremely high concentrations of $G$ aureolum.

Gyrodinium aureolum is only one among several phytoflagellates which has been shown to produce hemolysins or ichthyotoxins. Verity \& Stoecker (1982) studied the ability of tintinnids to feed and grow on the raphidophycean Heterosigma carteri (Hulburt) Taylor (often referred to as $H$. akashiwo or Olistodiscus luteus), an organism which also has been implicated in fish kills (Chang et al. 1990, Black et al. 1991). They demonstrated that ciliates were unable to sustain growth when fed a monoculture of this algae, irrespective of algal concentration. Lethal effects were observed sooner at concentrations exceeding ca $10^{3}$ cells $\mathrm{ml}^{-1}$. As in the present study, the authors failed to document toxic effects of filtrates.

\section{Ecological significance}

No data exist on the significance of zooplankton grazing during blooms of Gyrodinium aureolum in nature. Nevertheless, the present study suggests that monospecific blooms of G. aureolum are not substantially grazed by protozooplankton. This is supported by Bjørnsen \& Nielsen (1991), who found a dramatic reduction of protozooplankton numbers in a subsurface layer of algae heavily dominated by $G$. aureolum in the Kattegat, Denmark.

In an initial bloom phase, Gyrodinium aureolum will occur together with other phytoplankton species.
Will zooplankton survive/grow under such conditions? Experiments in which Favella ehrenbergii was fed mixtures of $G$. aureolum and the non-toxic algae Heterocapsa triquetra indicate that ciliates are able to maintain positive growth until $G$. aureolum make up a substantial fraction of the available algal biomass. In their study of the negative effects of Heterosigma carteri on ciliate growth, Verity \& Stoecker (1982) examined the ability of ciliates to sustain growth in mixtures of this toxic alga and an alternative prey. In experiments in which the ciliates were subjected to a fixed cell concentration of non-toxic prey and increasing cell concentrations numbers of the toxic $H$. carteri, they found that the ciliates were able to sustain maximum growth rate until $H$. carteri exceeded 12 to $14 \%$ of the available prey (in terms of biomass). The ciliates were unable to sustain growth when the concentration of $H$. carteri accounted for more than between 65 and $80 \%$ of the available food. At this concentration of $H$. carteri, the toxic effect was most probably due to toxic exudates in combination with ingestion of the alga. Thus, the experiments done so far suggest that ciliates can thrive among algae producing hemolysins/ichthyotoxins, as long as the concentration of these algae is low and the algae do not dominate the phytoplankton biomass.

Do the ciliates selectively avoid ingestion of Gyrodinium aureolum? It is well documented that the efficiency of particle capture in ciliates depends on the size of the particles (Heinbokel 1978, Fenchel 1980, Jonsson 1986). Some studies have found that ciliates take up artificial particles at a lower rate compared to natural particles of a similar size (Stoecker et al. 1986. Stoecker 1988), although this is not a general phenomenon (Fenchel 1986). In addition, a few studies (Heinbokel 1978, Stoecker et al. 1981) have suggested that ciliates can select between algae of comparable sizes, e.g. toxic algae from non-toxic ones (Stoecker et al. 1981). The present studies on the grazing by Favella ehrenbergii on G. aureolum/Heterocapsa triquetra suggest that the ciliate $F$. ehrenbergii cannot selectively avoid feeding on the non-nutritious $G$. aureolum. Thus, G. aureolum cannot escape grazing from ciliates until they completely dominate the phytoplankton community.

In conclusion, the available data suggest that monospecific blooms of Gyrodinium aureolum inhibit the growth and, subsequently, grazing of the proto- and mesozooplankton. This may be one of the reasons why these blooms can persist for several weeks. However, it is interesting that at least the protozooplankton may grow well when exposed to mixtures of $G$. aureolum and a non-toxic prey. A consequence of this is that $G$. aureolum cannot escape a potentially significant grazing loss in nature, unless the alga dominates the phytoplankton community. 
Acknowledgements. I am grateful to the Scandinavian Culture Collection, Department of Fungı and Algae, Copenhagen University, which provided the algal cultures and to Benni Hansen for the use of his infrared gas analyzer $l$ thank Tom Fenchel and Torkel Gissel. Nielsen for constructive criticism. I am indebted to Per Andersen, Bio/consult, and Bent Jensen, County of Viborg, for locating and bringing water samples containing the ciliate. This work was funded by the National Environmental Agency, Program Hav90, Contract No. 2.26 and the National Science Foundation Contract No. 11-0420-1.

\section{LITERATURE CITED}

Abé T, Hirayama K (1979) Lethal effect of Gymnodinium sp. on the rotifer, Brachionus plicatilis. Bull Fac Fish Nagasaki Unjv 46:1-6 (in Japanese, English abstract)

Arzul G, Erard-Le Denn E, Videau C, Jegou AM, Gentien P (1993) Diatom growth repressing factors during an offshore bloom of Gyrodinium of. aureolum. In: Smayda T, Shimizu Y (eds) Toxic phytoplankton blooms in the sea. Proceedings of the Fifth International Conference on Toxic Marine Phytoplankton. Elsevier, New York, p $719-724$

Bjørnsen PK, Nielsen TG (1991) Decimeter scale heterogeneity in the plankton during a pycnocline bloom of Gyrodinium aureolum. Mar Ecol Prog Ser 73:263-267

Black EA, Whyte JNC, Bagshaw JW, Ginther NG (1991) The effects of Heterosigma akashiwo on juvenile Oncorhyncus tshawytscha and its implications for fish culture. J appl Ichthyol 7:168-175

Braarud T, Heimdal B R (1970) Brown water on the Norwegian coast in autumn 1966. Nytt Mag Bot 17:91-97

Chang FH, Anderson C, Boustead NC (1990) First record of a Heterosigma (Raphidophyceae) bloom and associated mortality of cage-reared salmon in Big Glory Bay, New Zealand. NZ J mar Freshwat Res 24:461-469

Fenchel T (1980) Relation between particle size selection and clearance in suspension-feeding ciliates. Limnol Oceanogr 25:733-738

Fenchel T (1986) Protozoan filter feeding. Prog Protistol 1: $65-113$

Frost BW (1972) Effects of size and concentration of food particles on the feeding behavior of the marine planktonic copepod Calanus pacificus. Limnol Oceanogr 17 $805-815$

Garcia VMT, Purdie DA (1992) The influence of irradiance on growth, photosynthesis and respiration of Gyrodinium of. aureolum. J Plankton Res 14:1251-1265

Gentien P, Arzul G (1990) Exotoxin production by Gyrodinium cf. aureolum (Dinophyceae). J mar biol Ass UK 70 : $571-581$

Gill CW, Harris RP (1987) Behavioural responses of the copepods Calanus helgolandicus and Temora longicornis to dinoflagellate diets. J mar biol Ass UK 67:785-801

Hansen PJ (1989) The red tide dinoflagellate Alexandrium tamarense: effects on the growth and behaviour of a tintinnid ciliate. Mar Ecol Prog Ser 53:105-116

Heinbokel JF (1978) Studies on the functional role of tintinnids in the southern California Bight. I. Grazing and growth rates in laboratory cultures. Mar Biol 47:177-189

Helm MM, Hepper BT, Spencer BE, Walne PR (1974) Lugworm mortalities and a bloom of Gyrodinium aureolum Hulburt in the eastern Irısh Sea, autumn 1971. J mar biol Ass UK 54:857-869

This article was presented by $T$ Fenchel (Senjor Editorial Advisor), Helsinger, Denmark
Hulburt EM (1957) The taxonomy of unarmoured Dinophyceae of shallow embayments on Cape Cod, Massachusetts. Biol Bull 112:196-219

Jones KJ, Ayres P, Bullock AM, Roberts RJ, Tett P (1982) A red tide of Gyrodinium aureolum in sea lochs of the Firth of Clyde and associated mortality of pond-reared salmon. J mar biol Ass UK 62:771-782

Jonsson PR (1986) Particle size selection, feeding rates and growth dynamics of marine heterotrophic planktonic oligotrichous ciliate. Mar Ecol Prog Ser 33:568-572

Mahoney JB, Olsen P. Cohn M (1990) Blooms of a dinoflagellate Gyrodinium cf. aureolum in New Jersey coastal waters and their occurrence and effects worldwide. J coast Res 6:121-135

Nielsen MV, Strømgren T (1991) Shell growth response of mussels (Mytilus edulis) exposed to toxic algae. Mar Biol 108:263-267

Paasche E, Bryceson I, Tangen K (1984) Interspecific variation in dark nitrogen uptake by dinoflagellates. J Phycol 20 : $394-401$

Partensky F, Sournia A (1986) Le dinoflagellé Gyrodinium cf. aureolum dans le plancton de I'Atlantique Nord: identification, écologie, toxicité. Cryptog Algol 7:251-275

Potts GW, Edwards JM (1987) The impact of a Gyrodinium aureolum bloom on inshore young fish populations. J mar biol Ass UK 60:293-297

Roberts RJ, Bullock AM, Turner M, Jones K, Tett P (1983) Mortalities of Salmo gairdneri exposed to cultures of Gyrodinium aureolum. J mar biol Ass UK 63:741-743

Southgate $T$, Wilson $K$, Cross TF, Myers AA (1984) Recolonization of a rocky shore in SW Ireland following a toxic bloom of the dinoflagellate. Gyrodinium aureolum. J mar biol Ass UK 64:485-492

Stoecker DK (1988) Are marine planktonic ciliates suspension-feeders. J Protozool 35:252-255

Stoecker DK, Cucci TL, Hulburt EM, Yentsch CM (1986) Selective feeding by Balanion sp. (Ciliata: Balanionidae) on phytoplankton that best support its growth. J exp mar Biol Ecol 95:113-130

Stoecker DK, Guillard RRL, Kavee RM (1981) Selective predation by Favella ehrenbergii (Tintinnia) on and among dinoflagellates. Biol Bull 160:135-145

Tangen K (1977) Blooms of Gyrodinium aureolum (Dinophyceae) in north European waters, accompanied by mortality in marine organisms. Sarsia 63:123-133

Turner MF, Bullock AM, Tett P, Roberts RJ (1984) Toxicity of Gyrodinium aureolum: some initial findings. Rapp P-v Réun Cons int Explor Mer 187:103-108

Uye S, Takamatsu K (1990) Feeding interactions between planktonic copepods and red-tide flagellates from Japanese coastal waters. Mar Ecol Prog Ser 59:97-107

Verity PG, Stoecker DK (1982) Effects of Olistodiscus luteus on the growth and abundance of tintinnids. Mar Biol 72: $79-87$

Widdows J, Moore MN, Lowe DM, Salkeld PN (1979) Some effects of a dinoflagellate (Gyrodinium aureolum) on the mussel, Mytilus edulis. J mar biol Ass UK 59:522-524

Yasumoto T, Underdal B, Aune T, Hormazabal V, Skulberg OM, Oshima Y (1990) Screening for hemolytic and ichthyotoxic components of Chrysochromulina polylepis and Gyrodinium aureolum from Norwegian waters. In: Granéli E, Sundström B, Edler L, Anderson DM (eds) Toxic marine phytoplankton. Proceedings of the Fourth International Conference on Toxic Marine Phytoplankton. Elsevier, New York, p 436-440

Manuscript first received: November 1, 1993

Revised version accepted: March 3, 1995 